\title{
Coal is our strife: representing mining heritage in North East England
}

\begin{abstract}
This paper explores the history of representing coalmining heritage in museums between the 1960s and 1980s. The process of representing industry in museums during a period of significant economic change was highly contested. Whilst political and economic leaders often expressed a desire to vanquish the 'old black industrial image', there was a growing popular concern to venerate and represent an industrial culture and landscape that appeared under threat. At the same time the curation of industrial heritage, with its focus on collective memory, associational life and culture, represented a clear break with an earlier regional museum inheritance characterised by singular philanthropic and antiquarian collections and institutional developments. After 1960 the creation of museums to represent coalmining brought these tensions and new agendas to the fore. This article suggests that by examining in detail the historical context in which they were created we can better understand the nuanced and complex process of muzealisation and its relationship to the experience of economic change and deindustrialisation. Equally by analysing contextual shifts in relation to the curation of industrial heritage it is possible to observe how the process reflected the interests of different individuals, groups and organisations, including former miners, regional cultural officers and museum curators, local politicians and labour movement organisations. These perspectives have often been overlooked by the historical influence of the 1980s 'heritage debates'. Extending more recent historiography on the use of the past this article suggests that mining museums were central to the construction of historical consciousness and emphasises how regional museum projects that developed during times of economic uncertainty relied heavily on narrative tropes connected to the 'monumental' mode of history. This allowed the difficulties of the present to be clearly demarcated from the distant and celebrated past. Despite their differences, after the 1960s the emergence of mining museums represented a clear shift away from an antiquarian mode of historical consciousness that had characterised the earlier regional museum inheritance. This reflected a central tension between modernisation and decline expressed both through museum curation and in the external context of regional and economic policy. The nuances of these shifts, and their influence over museums, have often remained obscured by the ideological critical appraisal of heritage from the 1980s and 1990s.
\end{abstract}




\section{Coal is our strife}

The closure of Ellington colliery in 2005 marked the end of over 1000 years of coalmining in Northumberland and Durham. The 'longue duree' of activity in the 'Great Northern Coalfield' has often been represented as the anchor for a cohesive regional history and identity. Most notably geographer C.B. Fawcett's designation of a Northern England that was defined by coalfield activity produced government boundaries during the early twentieth century that reflected the industry's spatial reach. ${ }^{1}$ For Fawcett the economic predominance of mining across space and time, spawned an industrial economy based upon the interlinking of coal, iron and steel and heavy engineering, dubbed 'Carboniferous Capitalism' by Lewis Mumford. This notion of a modern regional identity underpinned by a widespread veneration of industry, produced a challenging context for the representation of industrial heritage in museums in the North East. These challenges were amplified by the accelerating decline, since the 1960s, of the coalfield as the major source of employment and associated economic activity. $^{2}$

The regional museum sector's main venue for industrial history was the Science Museum on Newcastle's Town Moor, housed in a building left over from the 1929 North East Coast Exhibition. The exhibits and displays reflected the museum's origins in the heydays of northern heavy industrial engineering. The nearby Hancock Museum was the region's major venue for Natural History, its ground floor dominated by displays of birds' eggs and stuffed animals reflected its Victorian origins and ownership by the Natural History Society of Northumberland and Durham. Other major towns in the North East had museums that housed similar collections. Fine and applied arts had traditional settings, the major ones being Newcastle's Laing Art Gallery and the Bowes Museum located on the Durham banks of the river Tees close to the market town of Barnard Castle. Specialist academic collections were housed in small university based museums at Durham and Newcastle.

From the 1960s regional museums evolved against a backdrop of increasing physical dereliction and loss, in which the decline of coalmining, shipyards and steelworks closures rapidly eroded the foundations of the region's industrial society and cultural identity.

Government economic policy in the 1960s underlined the tension between modernisation and decline. The location of newer, lighter industries into the region, with a growing emphasis upon the service sector during the 1980s, often became seen as dependent on the 'decline' of 
the old heavy industrial predecessors. Lawn mower factories, shopping malls and call centres were increasingly relied upon to take up the employment slack created by the demise of carboniferous capitalism. Ironically this economic policy resulted in museums themselves being perceived as part of the 'service sector' and mitigating against industrial decline, as sources of new economic activity, work and leisure to replace traditional sources of employment.

It is understandable that the representation of a failing old industrial order and its cultural heritage had little appeal to politicians and planners during the 1960s. Cultural policy during this period was aimed at encouraging the establishment of institutions such as orchestras that would attract the managerial class to relocate to a modernising region. ${ }^{3}$ The bad news of recent industrial history was best forgotten. During the 1980s, particularly in the aftermath of the Miners' Strike, the National Coal Board under the Conservative government were anxious to raze collieries and leave only blank green spaces. Stefan Berger has noted that in the South Wales coalfield 'After the government won this conflict in 1985 it decided the less of the region's history survived the better'. ${ }^{4}$ Berger's comparative study of industrial heritage in the Ruhr and South Wales highlights the celebrated centrality of mining in the Ruhr heritage narrative and its role in German economic re-structuring. ${ }^{5}$ In contrast Britain's coal regions have been riven by conflict and uncertainty since the Second World War and fit uncomfortably into the national discourse. ${ }^{6}$ Ironically the North East during the last three decades has become a leading international region in coalmining museum and heritage innovation with its institutions winning numerous distinguished awards and achieving impressive visitor numbers. ${ }^{7}$ All realised against a background of regional and national policy antipathetic to popular industrial heritage.

The process of representing industry in museums during a period of significant economic change was highly contested. Whilst political and economic leaders often expressed a desire to vanquish the 'old black industrial image', there was a growing popular concern to venerate and represent an industrial culture and landscape that appeared under threat. ${ }^{8}$ After 1960 the creation of museums to represent coalmining brought these tensions to the fore. This article suggests that by examining in detail the historical context in which they were created we can better understand the nuanced and complex process of muzealisation and its relationship to the experience of economic change and deindustrialisation. Equally by analysing contextual shifts in relation to the curation of industrial heritage it is possible to observe how the process reflected the interests of different individuals, groups and organisations, including former miners, regional cultural officers and museum curators, local 
politicians and labour movement organisations. ${ }^{9}$ This multiplicity of sometimes contradictory influences acknowledges the importance of museums to the construction of historical consciousness. As Aronsson has observed, regional museum projects that developed during times of economic uncertainty often relied heavily on narrative tropes connected to the 'monumental' mode of history, in which the difficulties of the present could be clearly demarcated from the distant and celebrated past. This theoretical framework allows the coalmining museums explored here to be understood as regional projects that were central mechanisms for the appreciation, understanding and negotiation of memories of the past as well as anxieties over the future. ${ }^{10}$

Two museums are analysed to understand this process between 1958 and 1989. The first museum is the now familiar case of Beamish Museum, County Durham. The creation of an open-air museum in 1971 is explored to understand how the context of a region coming to terms with major economic restructuring helped to shape the way in which historical consciousness was articulated at that time. ${ }^{11}$ The Beamish model closely mirrored the experience of an industrial region in flux, which informed a new curatorial approach that appeared to be radically different from the traditional, 'categorised' world of museums. Beamish's emphasis upon the recent history of the region and its 'bottom-up' collection policy proved to be an immediate success with the public, but was also criticised for its unashamed popular approach. During the 1980s, at the height of the debate over the 'heritage industry' Robert Hewison criticised the museum's approach for its production of ersatz public history. ${ }^{12}$

The second museum was constructed during the 1980s, which witnessed accelerated contraction of coalmining compounded by the crisis of the Thatcher years and the largest strike in the industry's history. This setting was a powerful and challenging context for the creation of Woodhorn Colliery Museum in Northumberland in 1989. Occupying the site of a former mine, the museum initiative started by local council cultural officers, reflected a strong local desire to create a prominent historical monument to mining. The curatorial strategy, which included locating within the museum the highly profiled collection of art depicting coalfield life by the 'Pitmen Painters', is understood here as integral to the musealization process. Compared to Beamish the development of collections and exhibitions maintained a singular focus upon the nobility of coalmining industrial heritage. ${ }^{13}$ This museum's foregrounding of the achievements and sacrifices of industry was all the more noteworthy for running counter to the 1980s appropriation of 'heritage', in the North East as elsewhere, as an 'adjective to help sell jewellery, picnic hampers and housing estates'. ${ }^{14}$ 
The creation of Beamish and Woodhorn museums corresponded to noticeable shifts in both public and private attitudes towards the representation of the British industrial past. A central historical problem for the analysis of the industrial museum has been the impact of the long shadow cast by the 1980s 'heritage debate'. For critics on the Left, the growing presence of marketized heritage and visitor experience sites within the representation of the past wilfully excluding challenging, radical or subversive memories of the past reinforced an ascendant service and managerial class. ${ }^{15}$ Following on from Hewison many industrial museums were cast as having a 'right wing bias' that consistently represented workers as compliant and industrious and where dead or declining industries achieved the highest profile, 'being safer topics than car manufacture or waste disposal'. ${ }^{16}$ This 'bias' was particularly problematic in the context of 1980s deindustrialisation, and the associated emasculation of organised labour, in which the 'heritagised memory space' of museums was arguably amongst the few spaces left in which working-class identities could be represented. ${ }^{17}$ The rise of the heritage industry in parallel with the 1980s challenge to working-class identities for some reinforced the burden of responsibility for museums. For Raph Samuel, this meant it was imperative to wrest the concept of heritage away from Thatcherism and to 'unleash it as a potentially radical force'. ${ }^{18}$ The creation of Woodhorn Colliery Museum, at the height of this heritage debate, as an ambitious monument to the industry, is a noteworthy example of how these challenges were mediated locally.

As noted by Samuel, the academic appraisal of the heritage industry from the 1980s brought its own challenges, not least the tendency to obscure the relationship to the longer history of industrial preservation and local museum development. This is borne out by the cases examined here with the creation and curation of Beamish and Woodhorn Museums that reflected many overlapping and recurring themes. This complexity can also be understood by extending the parameters to more recent historiography on the use of the past. Peter Mandler, for instance, has chosen to explore the social shifts since the 1960s which prompted large numbers of people to develop a growing interest in history and heritage. The decline of traditional industries, more free time, the growth in white collar work, new forms of associational life, easy access to motor cars have all served to radically change leisure patterns and interests. Since the 1960s Mandler has noted the rapid growth in readership of historical novels, non-fiction and television historical dramas and documentaries. ${ }^{19}$ The motor car has facilitated rising membership of the National Trust as visitors flock to the many different types of attraction run by the charity. Virtually all Trust properties have access to car parking. Suburbanisation and gentrification has also served to raise historical awareness, 
the stripped pine and Laura Ashley patterns of the early 1970s proto gentrified domestic interior raised the awareness of many people to architectural and social history. Mandler's focus upon the 'demand' factors for heritage and history is a useful corrective to previous explanations and one that emphasises the role of agency in steering the process of musealization.

North East England shared the demand factors identified by Mandler, albeit in a context of emphasising regional particularity. The historical fiction of Catherine Cookson and the historical drama of Alan Plater gained a strong local audience before achieving major national and international fame. ${ }^{20}$ Publisher Frank Graham produced a guide to Lindisfarne in 1958 followed by numerous local history books and pamphlets. ${ }^{21}$ This demand for local history produced its own soundtrack with the regional folk music revival of the early 1960s which was largely based on traditional songs and ballads. 22 The demand for historically based regional culture grew in inverse proportion to the decline of north east heavy industry, particularly the closure of coal mines initiated by the implementation of the County Durham Development Plan of $1951 .{ }^{23}$ Arguably the appetite for a historically informed popular culture was preceded by a rising interest in the material culture of the region.

The creation of Beamish Museum in County Durham and Woodhorn Museum in Northumberland undeniably contributed to the 'muzealisation' of the industrial past. But their capacity to influence this process did not evolve in an historical vacuum. They both reflected and were influenced by key shifts that allowed audiences to come into contact with the historical culture of mining in ways that were unprecedented. At Beamish the much profiled 'folk life' construction of coalfield life reflected a distinct break with the 'cabinet of curiosities' through which regional audiences would hitherto have encountered the past in the museum setting. The re-purposing of the museum concept arguably gave legitimacy to new approaches and extended the parameters for the curation of industrial heritage. In the North East this created a platform for the creation of Woodhorn Museum in the 1980s. The development of this much less profiled mining museum at the height of the 1980s 'heritage debates', provides an unprecedented insight into the cultural context for the 'end of coal' and the local responses this elicited. However, despite their differences, after the 1960s Beamish and Woodhorn represented a clear shift away from an antiquarian mode of historical consciousness that had characterised the earlier regional museum inheritance. The creation of two museums that corresponded to a monumental mode of history reflected a central tension between modernisation and decline expressed both through museum curation and in the external context of regional and economic policy. The nuances of these shifts, and their 
influence over museums, have often remained obscured by the ideological critical appraisal of heritage from the 1980s and 1990s.

\section{Beamish museum}

The 1960s and 1970s were important for the development of the open-air museum in Europe and North America. With origins in European national romantic 'folk' museums, the open air museum became an important model for the industrial, and especially coal mining, museum by the 1960s and 1970s. The international take up of the nineteenth-century folk museum assumed two discernible pathways by the 1960s. The continental European approach moved away from folksy populism towards a 'drier more museological' representation of industrial heritage, whereas in American museum culture the built environment of industry was by contrast seen more flamboyantly as 'stage sets for acted interpretation'. ${ }^{24}$ Beamish museum emerged as a hybrid of these forms, affirming that British industrial museums after the 1960s were not underpinned by a cohesive approach. ${ }^{25}$ The growing interest in industrial heritage was fragmented, locally contingent and nowhere was this more apparent than in the North East.

In 1958, Durham County Council's sub-committee for museums met to consider a recommendation that the region's collections of 'folk life' and industrial material should be identified and used to support the creation of an open air museum of northern coalfield life. This process lead to the creation of Beamish open air museum in 1971. Over the next decade the site for the museum on 200 acres of farmland near the town of Stanley was agreed and the collection built in preparation for the opening of Beamish, the North of England Open Air Museum, in 1971. ${ }^{26}$ The museum reflected noticeable shifts in the regional economic context, as well as in the national and local approach to museum curation. These are explored together with the development at Beamish museum of a highly distinctive 'open' curatorial approach, in order to understand better how the representation of mining heritage changed during the 1960s and 1970s.

Frank Atkinson, founder director Beamish museum, was brought up in a pit village near Barnsley. A graduate of Sheffield University, he had long nurtured an interest in museology. In 1949 this ambitious 29 year old was appointed director of the Wakefield City Art Gallery and Museum and then director of Halifax Museum. ${ }^{27}$ His career in the museums 
sector progressed swiftly and in 1958 he was appointed director of the Bowes Museum in County Durham, home to some of the region's most prestigious examples of French and Spanish fine and decorative art, including works by Goya. The purpose built museum had originally opened in 1892 and was the creation of John Bowes, the illegitimate son of John Bowes, the 10th Earl of Strathmore and Kinghorne and his wife Joséphine Chevalier, Countess of Montalbow. ${ }^{28}$ A grandiose building constructed in imposing French style, the museum faired less favourably in the twentieth century, experiencing falling visitor numbers and growing financial difficulties. These worsened after the Second World War and, following a particularly severe financial crisis in 1956, the museum 'joined many of the other palaces of great coal owners in the care of the [Labour Party and NUM dominated] Durham County Council'. Atkinson's appointment signalled a clear shift in the character of the Bowes Museum collections. Alongside the Bowes' richly varied collection of beaux arts Atkinson tried to 'fill every available space' in this 'palace of European culture' with industrial artefacts he had salvaged from the Durham coalfield. ${ }^{29}$ The impracticality of this approach and the unsuitability of Bowes Museum as a space within which working-class culture could be displayed was soon evident. Shortly after his appointment Atkinson proposed to his Council employers that an area with such a strong industrial heritage needed another museum to reflect everyday life and the more recent past. ${ }^{30}$

Initially Atkinson's proposal generated political support, but the creation of Beamish Museum evolved in an uncertain and rapidly changing economic context. On the one hand the region was buoyant and enjoyed a brief optimistic economic and political outlook. The Second World War temporarily revived coal mining and with the pits now belonging to 'the people', the industry came to symbolise the ambition for a modern Britain. This influenced life in the North East in multiple ways, not least through the bold initiatives to replace the slums housing of much of the region's mining population with modern, architect designed communities. County Durham was at the centre of this ambition with creation of New Towns in Peterlee and Aycliffe quickly coming to signify the triumph of planned and modern technocracy. Berthold Lubetkin, the seminal modernist architect appointed to plan Peterlee New Town during the 1950s described how he had embraced the opportunity to create in architectural terms the camaraderie that brought miners together through the danger of their work. Reflecting on the idealism of the period he later recalled that Peterlee New Town was intended to be the 'world capital of miners'. ${ }^{31}$ The commitment to building better futures was given a boost in the North East in 1963 following the appointment of Lord Hailsham as 
Minister with special responsibility for the area, signalling the Conservative government's response to growing demand for regional development policy. His brief included producing a strategy for reviving the region's heavy industries, and for ensuring that economic revival went hand in hand with improvements in infrastructure and communications. ${ }^{32}$ This policy evolved in the context of a palpable changes in the Durham coalfield during the 1960s; between 1962 and 1970, at least five mines were closed annually, peaking at sixteen mine closures in $1968 .{ }^{33}$ The intention was that this contraction would be offset by the opening of larger, more modern, coastal sites.

Peterlee, with its modernist houses and its science and technology park, was central to a vision of a modernized North and was designated an economic growth zone that also complemented the ambition to 'raise the standards of urban design throughout the region'. 34 The New Town was constructed to rehouse Durham miners living in poor housing conditions in villages designated as 'category D'. ${ }^{35}$ The experience of communities that inhabited the 'condemned villages' was often traumatic, with communities and families dispersed, local businesses, sites of sociability and the associated material culture of an industrial community fragmented. Locally and nationally these experiences highlighted the greatly contested experience of attempts to modernise the coal industry. ${ }^{36}$ Atkinson and his workers were alive to this context and his concern to preserve the material culture of the Durham pit village coincided with strong local anxieties over the future of these communities. With the destruction of the 'category D' villages in sight, this invested the project with a sense of popular urgency.

With support for the museum in place from the County Council by 1960 Atkinson made his first appointment in Anne Ward as 'folk life assistant'. Ward's responsibilities were principally to assist Atkinson with a process that engaged people throughout the region in collecting objects and artefacts of 'folk life' in preparation for the open-air museum. ${ }^{37}$ This job title was a clear departure for appointments within the municipal museums service before this time and reflected Atkinson's interest in the European open air museum concept and his desire to apply it in curating coalfield heritage. He explained that the inspiration for Beamish came from 'it's highly successful and popular Scandinavian forerunners', adding further that an earlier visit to the Lillehammer Folk Museum in Norway had persuaded him that there was a need for such a museum in England. His interest in this approach had led him to notice the contrast to Britain there had been no comparable national attempts to establish a British museum along the lines of the Scandinavian model. Atkinson would later distinguish 
Beamish from contemporary industrial museum developments where industrial archaeology was prioritised, such as Iron Bridge museum in Shropshire, emphasising his affinity with the Nordic pathway. Drawing on this international precedent he emphasised that in County Durham the museum would through its contents and the creation of an atmosphere conducive to enjoying the landscape of the past, be better able to demonstrate the region's uniqueness and particularity. 38

Skansen Museum in Stockholm, also visited by Atkinson, is a carefully constructed vernacular landscape in a metropolitan setting. Northern rural farmsteads jostle for space with late nineteenth century 'company towns' of middle and southern Sweden and Sami settlements of the arctic circle. ${ }^{39}$ These are located on a precipitous rocky site within the boundaries of the nation's capital, from where the national seat of power, Royal Palace and Houses of Parliament, are clearly visible. Skansen was constructed in the $1890 \mathrm{~s}$ at the height of the romantic nationalist movement and reflected elite fears that Sweden's political equilibrium might be unsteadied by Europe's revolutionary movements. During these years Skansen often hosted traditional festivals, such as Walpurgis and Midsummer, designed to 'win the ideological allegiance of the working classes'. ${ }^{40}$ By the time Atkinson visited the Nordic open air museums they had been subject to overhaul by modernist and Social Democratic impulses, and were often hosting large rallies for trades unions, labour movement associations as well as enjoying close links with the Social Democratic Party. ${ }^{41}$ In choosing to locate the museum at Beamish, Atkinson showed an awareness of how the relationship of the museum to its economic and political context might help to shape the representation of the past. But his approach was perhaps unexpected. The museum was not located with a view of a coalmine nor was it discernible from the 'pitman's parliament' (Durham Miner's Association Hall) in Durham City. When a regional working party to oversee the museum project proposed a number of different sites across Northumberland and Durham Atkinson argued persuasively for the use of the NCB owned Beamish Hall and the 200 acres of rural land surrounding it near the town of Stanley in County Durham. ${ }^{42}$ The relationship with the NCB was to be vital and smoothed the way for Atkinson to argue that the site's spatial advantages, and specifically its basin shape topography, would allow visitors to enjoy the atmosphere of the constructed colliery village without encountering the juxtaposition of the modern landscape outside the museum. Fully immersed in the museum setting they would be better able to be transported back to a time when mining communities were thriving. ${ }^{43}$

The 'corporatist' nature of the regional economy, dominated by the nationalised coal and steel industries and the vast Teesside chemical pants of ICI worked in Atkinson's favour 
and the regional Labour Party had long been dominated by the Durham Miners' Union and was famously dubbed 'The Checkweighman's Party' by Beatrice Webb. ${ }^{44}$ Atkinson strategically recruited Sir Derek Ezra, Chairman of the NCB as Appeal Fund President. Ezra with a first in History from Cambridge was sympathetic to the Beamish project and when workers unexpectantly unearthed the forgotten old Mahogany Drift Mine during site preparations he enthusiastically agreed to reopen the mine in 1979 and used the ceremony as an opportunity to publicise the Beamish Appeal Fund. Ezra and Atkinson clearly shared the same vision for Beamish, The NCB boss telling the audience at the ceremony that 'one of the most remarkable achievements at Beamish is that visitors like myself can not only learn something about the past but have a most enjoyable time doing so'. ${ }^{45}$ The NCB sponsorship of Beamish was reaffirmed by Ezra informing the visitors that 'the coal industry hopes to play a continuing part in the reconstruction and development of the project. We have been able to give technical assistance to make excavation of the coal seams possible and contributed early mining equipment for conservation at Beamish'. ${ }^{46}$

For the museum Atkinson located and secured the transfer of industrial objects that he had accumulated at Bowes Museum, extending this through an 'open curatorial' policy, which allowed local communities to identify and deposit material that they felt to be under threat of demolition, dereliction and neglect. ${ }^{47}$ Whilst the museum's spatial arrangement was carefully managed by Atkinson, there is little evidence that he or his team of assistants deviated much from the suggested openness of the 'you offer, we collect' principle to creating their collection. ${ }^{48}$ However, the careful management of the museum's internal landscape, and especially the curation of objects that were used to reconstruct the open air 'colliery village', undeniably allowed the past to be viewed through a new lens.

Beamish Museum's deviation from strict topographical and spatial authenticity attracted prominent critical appraisal within 'heritage debates' from the 1980s. The museum's flagship recovery of a steam winding engine house, salvaged from a disused mine half a mile from Beamish, is central to the contested responses it has evoked. On the one hand, local historians and mining aficionados praised the careful research and historical accuracy that informed the acquisition of such pieces as integral to the museum's ambition to safeguard items once common place in the mining landscape, but threatened during the 1960s with industrial 'extinction' by modernisation and decline. ${ }^{49}$ On site the machinery was reconstructed to meet the needs of the museum: it was powered by an electric engine with faux steam and whistles conveying the atmosphere of its original function. Features such as these were central to Hewison's critique of the production of ersatz public history ${ }^{50}$ Likewise 
the museum's drift mine was described as so 'assiduously cleansed and regularized to better permit comfortable gazing' that it bore little resemblance to actual work places of the past ${ }^{51}$ Such criticism does overlook the welter of safety legislation that has evolved in the industry since the drift ceased production and the strict measures that have to be adopted to facilitate public access.

It is important to recall that Atkinson's ambition was to create an atmosphere of the colliery village, and he was robust in his defence of an approach which compared favourably to the grassed over landscapes of colliery communities elsewhere in the country, but perhaps most obviously within the Welsh coalfield. Part of this atmosphere involved embracing the material culture of coalmining to complement the museum's built environment. From an early stage the museum would host and incorporate into its museum the language of the pit through engagement with folk song and by deploying actors to populate the colliery village who assumed the dress of the coalfield. The domestic interiors of the colliery village were a particular feature, with an emphasis upon homeliness, community and comfort that undeniably appealed to audiences affected by the trauma of loss associated with the clearance of the 'category D' villages. ${ }^{52}$ Whilst this emphasis undeniably nostalgically represented the history of the colliery village, Atkinson's work coalesced with a much broader cultural construction of vernacular identity during the 1960s that drew upon similar historical tropes. By the end of the 1960s, the celebration of nineteenth-century coalfield culture was reaching new audiences beyond the North East. In 1969 Close the Coalhouse Door, one of Britain's first dialect plays to reach a national audience, was screened on BBC 1 in the highly prized 'Wednesday Play' slot. The original play was written by novelist, former mineworker and NCB journalist Sid Chaplin. ${ }^{53}$ The 1969 adaptation was written collaboratively by Sid Chaplin, Bill Hayes and Alan Plater, with music by Alex Glasgow, and was an exuberant celebration of coalfield culture on stage. As Plater reflects: 'As far as my Tyneside is concerned, history began with the industrial revolution and everything I have written about the area springs from that perception... What I tried to do in Close the Coalhouse Door was to embrace the music-hall tradition-the jokes, the stand-up routines, the funny hats and above all, the subversive energy'. ${ }^{54}$

The engagement of music hall tradition was intended to engage audiences beyond the usual patrons of the local rep; part of Alan Plater's ambition to write plays for 'people who do not go to the theatre'. ${ }^{55}$ This had parallels in Atkinson's ambition to represent and engage the culture and lives of ordinary people in museums in ways that departed from 
orthodox museum curation. Moreover, the representation of coalfield life was encouraged and reflected across a number of institutions from regional and national cultural agencies, such as the Arts Council, regional art galleries and museums. After the 1960s the Great Northern Coalfield was often the setting for a flourish of state sponsored (including by the $\mathrm{NCB}$ ) initiatives that reinforced the miner as the signature of northern and working-class culture. $^{56}$ Many welcomed the opportunities to represent vernacular speech and the ways of ordinary working people in a manner that was unprecedented. ${ }^{57}$ But for others, the preoccupation with mining in metropolitan culture reinforced caricatures constructed during the 1930 s that contributed to provincial cultural marginality. ${ }^{58}$

The context of the 1960s coalfield decline needs to be kept in mind when comparing the period to earlier and later episodes of retrenchment which were more conflictual. The 'Category ' $\mathrm{D}$ ' closures were accompanied by the promise of coastal super pits with new housing and modern amenities. With the opening of large coastal collieries supplying the coking coal to regional iron and steel plants the future seemed assured. In 1973, Peter Walker, the Secretary of State for Industry announced his ten year expansion plan for the British steel industry, Durham coalfield's biggest customer, the most ambitious ever produced. ${ }^{59}$ Since the 1950 's miners who could not be accommodated in the eastern sector of the coalfield were offered, thanks to the NCB Transference Scheme, a new life in the modern collieries of South Yorkshire and the Midlands with their wide seams and modern machinery. The Scheme was encouraged during the 1950's and 60's by the NCB Chairman Alf Robens, formerly Labour MP for the mining seat of Wansbeck. Picks, shovels and ponies were to be replaced by mechanised cutting, loading and conveyer belts. The pit rows of West Durham were exchanged for new council housing in Kellingley, Ollerton, Coventry and even Kent. ${ }^{60}$ The disappearance of the Victorian mining landscape and its replacement with New Towns boasting Scandinavian architecture, light industrial estates and mechanised super pits presented new vistas where the past could become a subject of nostalgia especially when the present appeared so different and modern. ${ }^{61}$

Atkinson clearly exploited the opportunities of coalescing his museum initiative with this cultural and economic context. ${ }^{62}$ By the late 1970's interest in regional heritage was growing, in part influenced by the success of Beamish, but also the accelerating decline of traditional industries and thanks to the completion of planning schemes originally conceived in the late 1960s that dramatically altered parts of the urban landscape. The controversial redevelopment of central Newcastle was the most noted example and on a 
smaller scale townships such as Blaydon all but disappeared. ${ }^{63}$ This sense of loss was compounded by rising inflation and unemployment levels not seen for a generation. A visit to Beamish for a day, strolling through the bric a brac of the material culture of a vanishing world and inhaling the smells of boiler steam and burning coal undoubtedly provided an enjoyable and emotionally rewarding 'memory space' in this landscape of rapid change. ${ }^{64}$ The desire to retain connections to the past could also boost a sense of pride and belonging and provide a counterweight to the forces of anomie. ${ }^{65}$ It is not surprising that other places in the region wanted similar projects to Beamish.

\section{Woodhorn}

The Northumberland coalfield adjacent to Durham and sharing the same seams experienced similar decline and colliery closures. Ashington, renowned as the world's largest colliery village, suffered along with other towns and villages in the county. The announcement of the intention to close the local Woodhorn colliery in 1980 brought together a number of groups and organisations with ambitions to convert the mine into a museum. The NCB had entered into an agreement with Beamish to donate Woodhorn's fine headstocks. This seems to have spurred the local council to take action. Gerry White, Wansbeck District Council's Chief Leisure and Publicity Officer wrote a proposal to convert the colliery into an industrial museum in January 1981. White advised the Recreation and Amenities Committee that he had undertaken informal talks with the NCB and Northumberland County Council on the proposal and he was asked to prepare a detailed report for the District Council with capital costs and potential grants available for the scheme. ${ }^{66}$ Beamish withdrew their option on the headstocks allowing the acquisition of the colliery buildings in their entirety. ${ }^{67}$

Woodhorn was an attractive prospect for the local council and the wider South East Northumberland coal mining community. Frank Atkinson envisaged Beamish as an outdoor museum that would 'illustrate vividly the way of life... of ordinary people of the North East' ${ }^{68}$ By contrast Woodhorn would become an industrial museum dedicated solely to coal mining history and heritage.

St. Mary's church of Woodhorn, dating from the eight century was deconsecrated in the early 1970s and had been used as museum and exhibition space by the council, but the grade one listed building was poorly suited for its new role. The colliery site with its numerous buildings offered potential museum and gallery space and this prospect was pursued by George Stephenson the founder and leader of the highly acclaimed Mid Northumberland Arts Group (MidNAG). Stephenson had published works by Basil Bunting 
and Ivor Gurney as well as championing the Ashington Painters. ${ }^{69}$ Stephenson and the artist and journalist William Feaver successfully achieved national attention for the Ashington Group and they also persuaded the Group's trustees to permanently loan the collection to the new museum. The County Council could also envisage long term advantages from the site. Since local government reorganisation in 1974 the County Archives, located in the former urban district of Gosforth, was now outside of Northumberland and part of Newcastle upon Tyne. Combining the museum, gallery and archives in the same building was a tempting prospect.

There was also an important political dimension to the development of Woodhorn. Both the district and county councils were controlled by the Labour Party which drew its overwhelming support from the mining areas. The development of the new facilities based at the colliery was an important geopolitical statement, particularly as many expected art galleries and archives to be located in the middle-class county administrative town of Morpeth. The County Council was an equal partner in the realisation of Woodhorn particularly in its role in utilising government land reclamation grants to finance the conversion of the colliery into a museum. ${ }^{70}$ The County Council had already used reclamation funding to establish the Queen Elizabeth the Second Country Park adjacent to the colliery. The colliery spoil heaps were cleared under the reclamation scheme and the County Council agreed to use reclamation funds to purchase the site. There was even the potential of gaining Sports Council funding for the conversion of colliery buildings into facilities for outdoor activities in the park with its woodlands, open spaces and forty acre lake. ${ }^{71}$ The combination of the colliery museum and the country park made a perfect venue for the annual Northumberland Miners Picnic, the county's equivalent of the Durham Miners Gala and ended the considerable organisational problems created by the Picnic's former location in small mining towns.

The advocates of the Woodhorn project were fortunate in a number of ways. The NCB during the early 1980s was not hostile to mining heritage and had recently commissioned the research and production of the multi volume History of the British Coalfield $^{72}$. Wansbeck Council wrote to Sir Derek Ezra the Board chairman, heritage enthusiast and Beamish supporter, enquiring about the possibility of buying Woodhorn upon its closure and he replied that he had no objections to the project and told the Council to undertake negotiations with the NCB's regional management. ${ }^{73}$ When the County and District Council met with regional NCB officials, Mr Hirst the Deputy Director of the NCB North East Area, expressed support for the proposal, but candidly asked that publicity be kept 
to a minimum as he "had great difficulties because of the number of similar requests the NCB was receiving from other local authorities with similar ambitions'. ${ }^{74}$ Hirst then informed the meeting that the buildings on the site had been valued at $£ 3,700$, but the Board would be willing to accept a payment of only $£ 700$ which to no surprise was accepted by the County and District Councils agreeing to divide the cost between the two bodies.

This decision making process took place against a national backcloth when the Conservative government were in the early stages of implementing what would later be dubbed 'Thatcherism' with its emphasis upon reducing the role of both the central and local state. The announcement by the government in January 1981 that twenty three loss making mines were to be closed heralded a new era of confrontation. The threat of strike action forced the government to back down, but the corporatist period of the 1970s Labour government was clearly coming to a close. ${ }^{75}$ This threat to the industry was deeply felt in the North East where unemployment rates rose from $7.2 \%$ in 1976 to $18.1 \%$ in $1984 .{ }^{76}$ Lord Ezra retired later in 1982 and Ian MacGregor who took over as NCB chairman in 1983 was notoriously hostile to the miners' union and adopted an industrial relations strategy of confrontation. The policy of 'razing' collieries and hostility to coalmining heritage analysed by Berger in South Wales was initiated under MacGregor's chairmanship of the NCB. One of the first policies of the Conservative government elected in 1979 was the Local Government, Planning and Land Act of 1980 one of its aims was to control local government direct labour organisations, particularly by introducing competitive tendering. A survey of the colliery buildings undertaken by the District Council revealed the need for major refurbishment and repairs to roofs and floors. ${ }^{77}$ By the end of 1982 the possibility of using the council's own direct labour workforce on the colliery site was potentially hazardous, risking criticism from central government. ${ }^{78}$ Fortunately the museum was able to summon assistance for the construction work from another public sector organisation.

The Manpower Services Commission was established in 1973 by Edward Heath's Conservative government. The Commission was charged with coordinating and streamlining the various government employment and training programmes. ${ }^{79}$ The urban riots of 1981 and rising levels of youth unemployment prompted the government to expand training programmes to the benefit of many public sector projects. The MSC established a Community Programme Agency within the Wansbeck area where youth unemployment was rising rapidly and traditional industries contracting. ${ }^{80}$ The museum project with its long list of construction and refurbishment tasks was an ideal venue for the Agency and the MSC inaugurated a major scheme to carry out work at Woodhorn. ${ }^{81}$ The following year saw the 
formal transfer of the Woodhorn Church collection to the museum and the museum opened in 1989 when the Ashington Group Trustees agreed to permanently loan their collection along with Oliver Kilbourn's 'My Life as Pitman' paintings.

Visitors have a very different experience at Woodhorn in comparison to Beamish. Woodhorn is a site devoted to the single industry of mining. The buildings are pristine but stark, being mainly constructed out of colliery brick which adds emphasis to their authenticity. The initial stage of Woodhorn opened in 1989 with a site that consisted of the original colliery buildings. There was no attempt to create another Beamish or to stray away from the integrity of the colliery. In 1991 the Ashington Miners' memorial commemorating the 1916 Woodhorn colliery disaster was moved from a local park and given a prominent site between the visitors car park and the museum entrance, this striking monument's statue of a miner with pick and lamb was designed by the Newcastle architect W. H. Knowles and heralds the museum's commitment to presenting the harsh realities of coalmining. When the regional museum service surveyed the status of mining heritage in the North East, the investigator reported that "The site is exposed with buildings standing in isolation... The appearance can be desolate, visitors left with a feeling of abandonment in a site that will be uninviting to some ' 82 The opening ceremony conducted by Neil Kinnock on June $9^{\text {th }}, 1989$, went unreported in the regional press and the local weekly newspaper carried a photograph of Kinnock, but no accompanying commentary. ${ }^{83}$ The regional press did extensively report Kinnock's visit to Beamish the following day to open the Great North Family Gala which attracted 14,000 people drawn by the museum's extra attractions, similar to an early summer fair, staged for the event. ${ }^{84}$

Woodhorn museum was assembled during one of the bleakest periods in coalmining history and does not shy away from this reality. In 2006, a post coal and (late New Labour) moment lottery funding secured the second stage of the museum with the opening of the Cutter Building designed by Tony Kettle. This strikingly modern structure, inspired by a coal cutting machine, houses the County Archives, the Ashington Group paintings and various exhibitions. The main walkway through the building is dominated by the Miners Union Lodge banners, donated by the NUM, displayed hanging above the visitors with their colourful illustrations and strident political messages. Strikes, mining disasters and community hardship are depicted clearly and there is a genuine concern to avoid romanticising the past. The only images of coalfield domestic life are those depicted in some of the Ashington Group paintings. 
Woodhorn clearly owed a strong debt for its existence to the local labour movement: the Labour Party and the Mineworkers Union were the dominant political force local and county politics during the 1980 s, with many activists in both organisations. ${ }^{85}$ But it is important not to lose sight of other groups and personalities who helped in the establishment of the museum. Senior Council officers with responsibilities for cultural activities helped to plant and nurture the idea for the Woodhorn project. Gerry White the Chief Leisure and Publicity Officer lobbied the Council and compiled the early reports that set the process in motion. His deputy was George Stephenson formerly librarian at the local technical college and mining school and founder of MidNAG. Through the local Ashington festival Stephenson brought string quartets to the town and the Royal Shakespeare Company to nearby Newbiggin. In the words of William Feaver Stephenson's advocacy of the Ashington group 'pressured me into writing my book Pitmen Painters (1988), from which Lee Hall derived his 2007 play The Pitmen Painters, which took George's MidNAG values all over the world, most recently to Broadway'. His strong belief that everyone should have access to the arts, produced events, publications and the internationally famous MidNAG poetry posters series and these activities need to be seen as foregrounded by the celebration of vernacular culture that had been awakened in the North East during the 1960s. ${ }^{86}$

Today these two elements continue to define the museum. The realism of coalfield life is displayed in the same building as the County archives, the search room of which is populated by professional staff, historians, genealogists, members of the public on a personal search and legal researchers. Museum and archive visitors use the same entrance and share the café and other facilities. The museum does host popular events such as brass band festivals and the Miners Picnic which are closely linked to the coalfield. Yet this ethos is in a state of flux. It is over thirty years since the end of the miners' strike and for local audiences the working coalfield is a distant memory. The MidNAG tradition, however, remains strong and plays a prominent part in the life of the museum. Artist exhibitions of paintings, sculpture and installations, many with an industrial theme, have a regular programme. Susan Stenger's 2016 Sound Strata of Coastal Northumberland is a good example of Woodhorn's exhibition programme. Stenger displayed the twelve and a half metre side drawing of the strata of the Northumberland coast drafted by Nicholas Wood, a nineteenth century mining engineer, and composed a musical score that was inspired and reflected the beauty of Wood's illustration and the ever changing strata of the coastline. Woodhorn's proximity to the coast provided agreeable space for this ambitious and highly acclaimed work. ${ }^{87}$ 
Not every attempt in the region to preserve a significant industrial site escaped the broader national trend towards the razing of industrial heritage during the 1980s. Gateshead Metropolitan Council submitted a bid in 1983 to the Secretary of State to the Environment to stage a future National Garden Festival. The site earmarked by the Council for the festival was one of the most historic areas that played an important role in the early stages of the industrial revolution. ${ }^{88}$ The area had contained numerous collieries, ironworks, a twenty five acre former gasworks, coal tar plant and listed coal staithes reputed to be the world's largest wooden structure. The Council proposal was to incorporate much of this heritage into the Festival: aerial walkways would link the tops of four gasholders; the staithes would house a maritime museum dedicated to the area's collier tradition; the riverside soap works was to be turned into a cultural 'Palazzo' and the redundant Dunston power station was to become an art gallery. ${ }^{89}$ This vision was swept aside as 'Whitehall felt it necessary to reconstruct the image of urban areas as a counter to the media image of decay'. ${ }^{90}$ The Festival management at Gateshead was given to an American company with little local democratic input and O'Toole and Robinson noted that 'the emphasis is increasingly on Festivals as temporary theme parks which then provide a site for subsequent property development.' 91 The festival hosted fifteen thousand hours of events with little in the way of heritage; the gasworks were demolished and a Ferris Whennbel installed, displays by strong man Geoff Capes and exotic visits by Trobriand Islanders were typical fare. Part of the initial site including the power station was incorporated into the Metro Centre shopping mall and the remainder sold for housing. After the festival apart from the Staithes all of the historic structures and remnants of carboniferous capitalism had been removed.

Beamish and Woodhorn present different approaches to the representation of North Eastern mining heritage. Beamish was conceived during the 1960's when dramatic changes to the regional coalmining industry were benignly managed. A world was being lost but the future appeared bright and Beamish held the promise that the past could be revisited and nostalgic yearnings assuaged. It has proved an enduring formula and the Museum's programme of 'updating' ensures that post coal generations can enjoy a similar experience in a simulacra 1950s and 60s milieu of coffee bars, cinemas and prefabs. Woodhorn in contrast was largely assembled during the coal industry's most conflictual decade: a period when central government was often hostile to miners and their communities. Woodhorn memorialises a former industry and prompts the visitor to reflect on the sacrifices and achievements of working in a coal mine. The development of this much less profiled mining 
museum provides an unprecedented insight into the cultural context for the 'end of coal' and the local responses this elicited. As we have seen, there was an important political dimension to the development of Woodhorn; it owed a strong debt for its existence to the local labour movement. But the museum was also fortuitous in securing political support before 1983, the subsequent government hostility to the miners' union fundamentally changed attitudes towards coalmining heritage. Its creation was nonetheless due to more than just good luck. It drew on a broader platform for the representation of coalfield culture that had been a central element of Beamish's success. Frank Atkinson had been alive to the complementarity of regional cultural renaissance and his own ambition that moved away from more patrician forms of cultural representation. The re-purposing of the museum concept arguably gave legitimacy to new approaches and extended the parameters for the curation of industrial heritage. The development of Woodhorn at the height of the 1980s 'heritage debates', provides an unprecedented insight into the cultural context for the 'end of coal' and the local responses this elicited. The historical context for the formation of the two museums is a useful insight into the construction of coalmining heritage after the 1960s that is missing from retrospective critiques of the heritage sector.

\footnotetext{
Notes

${ }^{1}$ Fawcett, Provinces of England. Lancaster "The North East,", 23-43.

2 Lancaster "The North East, " 35-6; Dintenfass, Managing Industrial Decline. The Great Northern Coalfield had been in decline since end of the First World War, but decline was spasmodic as war time contingency brought temporary respite and there were marked differences of fortune within the coalfield.

${ }^{3}$ Vall, Cultural region.

4 Berger, "Representing the Industrial Age," 25.

${ }^{5}$ Ibid. Berger notes the 400 kilometres of heritage trails linking the 120 industrial sites that form the North Ruhr Emscher Park are anchored by former coal mines. This compares to the two mining mus eums in South Wales.

6 Ibid. 27-8; Arnold, "De-Industrialization," 34-60.

7 https://www.beamish.org.uk/news/bronze-for-beamish/. Accessed 15 February 2017. In 2016 Beamish museum was ranked in the top three museums nationally for 'large visitor attractions', https://www.beamish.org.uk/news/bronze-for-beamish/
} 


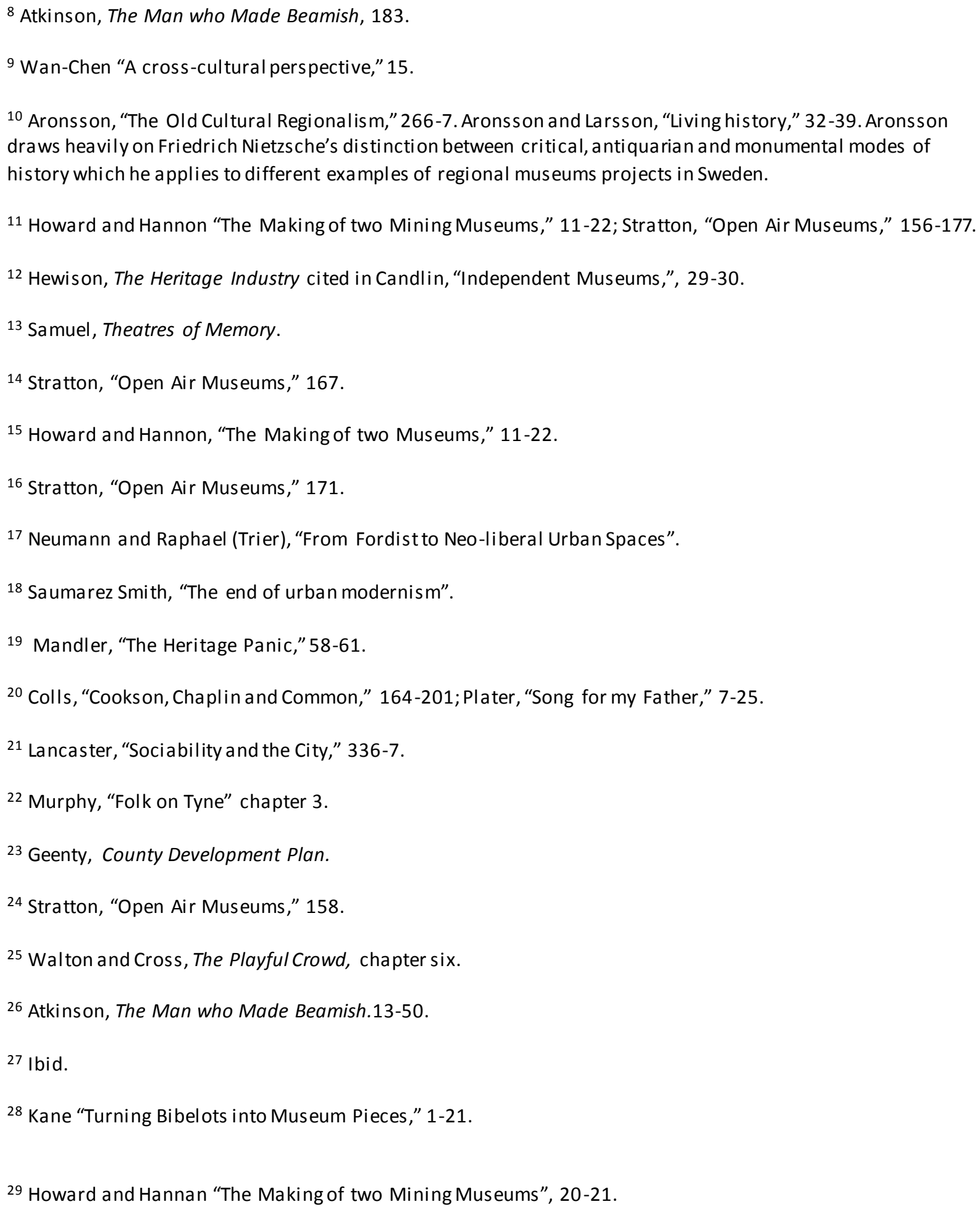

${ }^{31}$ Berthold Lubetkin, cited in Philipson, Aycliffe and Peterlee New Towns, 58. William (Lord) Beveridge, the architect of the welfare state became an Aycliffe resident, living at 3 Peaseway. 
32 The North East.

33 Saunders, "Beamish Open Air Museum," 2.

${ }^{34}$ The North East.

35 In County Durham's 1951 Development plan colliery villages were designated category A-D depending on the level of dilapidation, with those designated Category D identified for demolition and residents relocated, principally to the two New Towns of Newton Aycliffe and Peterlee.

${ }^{36}$ The experience of both rapid change and tragedy touched local communities and was reinforced nationally by traumatic events such as the Aberfan colliery disaster in 1966.

${ }^{37}$ Atkinson The Man who Made Beamish, 85.

${ }^{38}$ Atkinson, "An open air Museum for the North East," 1; TWAS, LA/PA/806, 15-16.

${ }^{39}$ Bergström and Edman, Folkhemmets Museum. 35-70.

${ }^{40}$ Conan. "The Fiddler's Indecorous Nostalgia," 112.

41 Ibid.

42 Beamish Working Party, "Report on Availability of Sites," 2.

43 Saunders, "Beamish Open Air Museum," 20.

${ }^{44}$ Middlemas, Politics in Industrial Society; Dintenfass, "Politics in Industrial Society," 63-6; Beynon and Austrin, Masters and Servants, chapter 11.

${ }^{45}$ Coal News, May, 1979

46 Ibid

${ }^{47}$ Atkinson, The Man Who Was Given a Gasworks.

48 TWAS, LA/PA/806, "Beamish, First Report," 15-16.

49 Doyle, Mining: the Beamish Collection, 9.

50 Hewison, The Heritage Industry, 95.

51 Trimm, "Taking you Back," 541.

52 Dennis et al, Coal is Our Life is the best known sociological study of the harsher aspects of coalfield life. Benney, Charity Main is a classic ethnographic account of life in Tanfield, a colliery village that was to be declared 'Category 'D' 'in 1951.

53 Vall, "Polishing the Pitmen,"163-180; Plater, "Song for my Father," 12.

54 Plater, "Song for my father," 14-15.

55 Ibid. 
${ }^{56}$ Both Sid Chaplin and the artist Norman Cornish were mineworkers whose transition to careers in the arts was encouraged and materially assisted by the NCB.

57 Plater, "Song for my Father," 12.

58 Shields, Places on the Margin. 219.

${ }^{59}$ British Steel Corporation Ten Year Strategy.

60 Taylor Migration from the Durham Coalfield remains the fullest account of this migratory episode.

${ }^{61}$ Crudens, Crudens Build with Skarne.

62 TWAS, “Beamish, First Report," 15-16.

63 Faulkner, “Architecture in Newcastle," 238-242.

64 Berger, "Representing the Industrial Age," 15.

65 Aronsson "The old Cultural Regionalism," 251-71.

${ }^{66}$ Northumberland County Archives (NCA), DC/W/A/11, 633/80.

${ }^{67}$ NCA, DC/W/A/13-438-81. Beamish was reliant upon financial assistance from most reginal local authorities and would have been be reluctant to engage with ownership disputes with donating bodies.

${ }^{68}$ Atkinson, The Man who Made Beamish. 84.

69 The Guardian, February 1 2011. Stephenson was librarian at Ashington Mining School and college and later succeeded White as the senior cultural officer for Wansbeck Council.

70 NCA, DC WA/13-569/81. Gateshead Council used land reclamation funds to clear and 'green' industrial sites that were polluted and dishevelled after more than a century of chemical and mining activities. These green sites were exploited by the borough's arts team and provided the platform for Gateshead's public arts programme. Vall Cultural Region, 148-163.

71 Ibid.

72 Mathias, British Coal Industry.

73 NCA, DC//WA/14, Meeting 23 June 1982, Appendix A

74 Ibid

75 Fine, The Coal Question, 158-62

76 Labour Gazette, 1984.

77 NCA, DC/WA/13-433-81, 19 November, 1981.

78 Loughlin, Local Government, 167-171.

79 Evans, Training Market.

${ }^{80}$ NCA DC/W/A/15-442/82, 28 October 1982

${ }^{81}$ NCADC/W/A15-521/82. 18 November, 1982 
82 Gale, Fuel for Thought. 63.

83 New Post Leader, June 15, 1989.

84 The Journal, June 10, 1989.

85 The current MP for Wansbeck, lan Lavery, was formerly a mineworker, activist in the 1985 strike, Chair of Wansbeck District Council, General Secretary of the Northumberland Miners Union, President of the National Union of Mineworkers, 2002-10. He is also Chair of the Trustees of the Ashington Painters Group.

${ }^{86}$ Feaver, "George Stephenson Obituary".

87 Stenger, Sound Strata. Nicholas Wood was the first President of the North of England Institute of Mining Engineers.

88 Levine and Wrightson, Industrial Society; Flinn, Men of Iron.

${ }^{89}$ Gateshead MBC, August 31983.

90 O'Toole and Robinson, Garden Festivals, 4.

${ }^{91}$ O’Toole and Robinson, Garden Festivals,16.

\section{Bibliography}

Arnold, Jörg. "De-Industrialization: A Research Project on the Societal History of Economic Change in Britain (1970-90)." German Historical Institute London Bulletin 34, no. 2 (Nov 2012), p34-61

Aronsson, Peter. "The old cultural regionalism and the new", in An Agenda for regional history Lancaster, Newton Diana, and Vall Natasha eds. 2007. Newcastle: Northumbria University Press, 2007.

Aronsson, Peter and Larsson, Erika. "Living history,": Cultural policy, museum strategy and learning response." Journal of Education in Museums. 23 (2002), 32-39

Atkinson, Frank. The man who made Beamish: An autobiography. Gateshead: Northern Books, 1999.

Atkinson, Frank. "An open air Museum for the North East". The Journal of Industrial Archaeology. 1 (1964-5), 
Benney, Mark. Charity Main: A Coalfield Chronicle. London: Allen and Unwin, 1946.

Berger, Stefan. "'Representing the Industrial Age: Heritage and Identity in the Ruhr and South Wales," in The Invention of Industrial Pasts: Heritage, Political Culture and Economic Debates in Great Britain and Germany 1850-2010, 14-36 edited Itzen Peter and Christian Muller, Augsburg: Wissner Verlag, 2013.

Bergström, Anders and Victor Edman, Folkhemmets Museum. Byggnader och rum för Kulturhistoriska Samlingar. Stockholm, Byggförlaget, 20052005.

Beynon, Hugh and T. Austin, Masters and Servants, Class and Patronage in the Making of a Labour Organisation: The Durham Miners and the English Political Tradition. River Oram: London, 1994.

British Steel Corporation: Ten Year Strategy. London: HMSO, 1973.

Crudens, Crudens build with Skarne (1967), Film ID: 19268, North East Film Archive (NEFA)

Dintenfass, Michael. Managing Industrial Decline: The British Coal Industry Between the Wars. Columbus: Ohio State University Press, 1992.

Dintenfass, M. "Politics in Industrial Society". Society for the Study of Labour History. 41 (1980) p63-6

Colls R., and Bill Lancaster, Newcastle upon Tyne a Modern History. Chichester: Phillimore, 2001 .

Dennis, N. F. Henriques, and C. Slaughter. Coal is Our Life: an Analysis of a Yorkshire Mining Community. London: Tavistock, 1974.

Doyle, Aidan. Mining: the Beamish Collection. Newcastle, Northumbria University Press, 2001 .

Candlin, Fiona. "Independent Museums, Heritage and the shape of Museum Studies". Museum and Society March. 10 (2012), p28-41. 
Conan, Michael. "The fiddler's indecorous nostalgia." In Theme Park Landscapes: Antecedents and Variations, edited Young Terence and Robert Riley. Washington: Dumbarton Oaks, 2002.

Coal News, May, 1979

Colls, R. 'Cookson, Chaplin, Common, Three Northern Writers in 1951'.'In The Regional Novel in Britain and Ireland: 1800-1990, 161-201, edited Snell, K., Cambridge, Cambridge University Press, 1999

Evans, B. The Politics of the Training Market. London: Routledge, 1992.

Fawcett, C. B. Provinces of England: A study of some geographical aspects of devolution. London: Hutchinson, London, 1929.

Fine, Ben. The Coal Question: Political Economy and Industrial Change from the Nineteenth Century to the Present Day. London: Routledge Revival, 2013.

Gale, Alison. Fuel for Thought: The Status and Future of Coal mining Collections in North East Museums. Newcastle upon Tyne: North East Museum Service, 1994.

Gateshead Metropolitan Council Planning Department, 'Gateshead Bid to the Secretary of State for the Environment to Stage the 1989 National Garden Festival.' Gateshead MBC, 1983.

Geenty, William County Development Plan. Written analysis prepared for the County Council of Durham, Durham County Council 1951.

Hewison, Robert, The Heritage Industry: Britain in a Climate of Decline. London: Methuen, 1987.

Howard, Stuart and Hannam, Kevin. "The making of two mining museums: Bowes and Beamish, North East England" in Mining Heritage and Tourism: A Global Synthesis. Conlin, Michael and Lee Joliffe eds. London: Routledge, 2010. 13-22.

Kane, Sarah "Turning Bibelots into Museum Pieces: Josephine Coffin-Chevalier and the Creation of the Bowes Museum, Barnard Castle.” Journal of Design History. 9, 1 (1996), 121. 
Labour Gazette, 1984.

Lancaster, Bill “The North East: England's most distinctive region?" in An Agenda for Regional History Lancaster, Bill, Diana Newton and Natasha Vall eds. Newcastle:

Northumbria University Press, 2007. 23-43

Levine, David and Wrightson, Keith. The Making of Industrial Society, Whickham 15601765, Oxford: Oxford University Press, 1991.

Loughlin, Michael. Local Government in the Modern State. London: Sweet and Maxwell, 1986.

Mandler, Peter. "The Heritage Panic of the 1970s and 1980s in Britain," in The Invention of Industrial Pasts: Heritage, Political Culture and Economic Debates in Great Britain and Germany 1850-2010, 58-70, edited Itzen Peter and Christian Muller, Augsburg: Wissner Verlag, 2013.

Mathias, Peter, Ed. The History of the British Coal Industry: Volumes 1-5. Oxford: Oxford University Press, 1986.

Middlemas, Keith, Politics in Industrial Society: The Experience of the British System since 1911. London: Andre Deutsch, 1979.

Murphy, Judith, "Folk on Tyne: Tyneside culture and the second folk revival, 1950-1975". PhD diss., Northumbria University, 2007.

Neumann, Arndt and L. Raphael (Trier), "From Fordist to Neo-liberal Urban Spaces in times of De-industrialization: A conceptual frame for a complex relationship", The Deindustrialising city: urban, architectural and socio-cultural perspectives workshop. German Historical Institute: London, 2016.

Northumberland County Archives, (NCA), DC/W/A/11, 633/80, 15th January 1981

NCA, DC/W/A/13-438-81.

NCA, DC WA/13-569/81

NCA, DC//WA/14, Meeting 23 June 1982, Appendix A

NCA, DC/WA/13-433-81, 19 November, 1981 
NCA DC/W/A/15-442/82, 28 October 1982

NCADC/W/A15-521/82. 18 November, 1982.

O’Tool M., and F. Robinson, Garden Festivals and Urban Regeneration, Newcastle:

Calouste Gulbenkian Foundation, 1990.

Plater, Alan. "Song for my father: The C. P. Taylor Memorial Lecture." Northern Review. 3 (1996): 7-25

Philipson, G. Aycliffe and Peterlee New Towns 1946-1988: Swords into Ploughshares and Farewell to Squalor. Cambridge: Publications for Companies, 1988.

Schwarz, Bill "Conservatism and Class Struggle: Politics in Industrial Society', by Keith Middlemas," Capital and Class. 12 (1980) 136-148.

Stratton, Michael. "Open Air Museums: Windows on to a Lost World or Graveyards for Unloved Buildings?" in Preserving the Past. The Rise of Heritage in Modern Britain, edited by Michael Hunter, 156-195, Stroud: Alan Sutton Publishing Ltd., 1996.

Saunders Rebecca, "Beamish Open Air Museum and the Preservation, and Representation, of Northern Industrial Heritage as a gendered process", MA diss., Teesside University, 2015. Saumarez Smith, Otto, "The end of urban modernism." The De-industrialising city: urban, architectural and socio-cultural perspectives workshop. German Historical Institute: London, 2016.

Shields, R. Places on the margin: Alternative geographies of modernity (London, Routledge, 1991).

Stenger, Susan. "Sound Strata of Coastal Northumberland," AV Festival, Newcastle upon Tyne, 2015.

Taylor, R. C. "The implications of Migration from the Durham Coalfield," $\mathrm{PhD}$, diss. University of Durham, 1966.

The North East: a Programme for Development and Growth Cmnd 2206, London: HMSO, 1963.

Trimm, R. S., "Taking you Back: Region, Industry and Technologies of Living history at Beamish," European Journal of Cultural Studies 15 (2012), 528-46. 
Tyne and Wear Archive Service, (TWAS) LA/PA/806, Beamish, First Report of the Joint Committee of the North of England Open Air Museum, 1978, 15-16.

TWAS, LA/PA/806, Beamish Working Party, Report by Museum Advisor, Frank Atkinson Director Bowes Museum, on Availability of Sites, 4 January 1967.

TWAS, LA/PA/806, Beamish, First Report of the Joint Committee of the North of England Open Air Museum, 1978, 15-16.

Vall, N. '‘Polishing the Pitmen': Cultural Improvers in North East England 1920-1960', Northern History, 41: 1 (2004), 163-180.

Vall, N., Cultural region. North East England 1945-2000 (Manchester: Manchester University Press, 2011).

Walton, John and Cross, Gary (Eds) The Playful Crowd: Pleasure Places in the twentieth century New York: Columbia University Press, 2005.

Chang Wan-Chen 'A cross-cultural perspective on musealization: the museum's reception by China and Japan in the second half of the nineteenth century', Museum and Society 10. 1 (2012), 15-27. 